\title{
Implications of the use of Strontium Ranelate (SRAN) in periodontics, dental implantology, oral surgery, orthodontics and endodontics and its possibility of application as storage media for avulsed teeth
}

Implicações do uso de Ranelato de Estrôncio (SRAN) em periodontia, implantologia dentária, cirurgia oral, ortodontia e endodontia e sua possibilidade de aplicação como meio de armazenamento para dentes avulsionados

Implicaciones del uso de ranelato de estroncio (SRAN) en periodoncia, implantología dental, cirugía oral, ortodoncia y endodoncia y su posibilidad de aplicación como medio de almacenamiento de dientes avulsionados

Amanda Cristine dos Santos BRITTO Dental School of Presidente Prudente, University of Western São Paulo - UNOESTE, Presidente Prudente - SP, Brazil https://orcid.org/0000-0002-2438-8922

Priscila Bruna Gonçalves LACERDA

Dental School of Presidente Prudente, University of Western São Paulo - UNOESTE, Presidente Prudente - SP, Brazil https://orcid.org/0000-0001-8914-3355

Victor Eduardo de Souza BATISTA

Dental School of Presidente Prudente, University of Western São Paulo - UNOESTE, Presidente Prudente - SP, Brazil https://orcid.org/0000-0003-0246-8101

Christine Men MARTINS

Dental School of Presidente Prudente, University of Western São Paulo - UNOESTE, Presidente Prudente - SP, Brazil https://orcid.org/0000-0002-5429-509X

\section{Abstract}

Dental avulsion is still public health problem and tooth replantation has important unsuccess rates due to root resorption. Strontium ranelate (SRAN) presents antiresorptive property on the bone tissue and stimulates bone formation. So we aimed to comprehensively review the literature to 1 - understand the mechanism of action of SRAN regarding to its propaedeutic in periodontics, dental implantology, oral surgery, orthodontics and endodontics, 2- present the current scientific knowledge about the SRAN efficiency on tooth avulsion; 3- observe fails and gaps in the literature and open up for unexplored ideas for SRAN uses and applications. An electronic search was performed crossing the key words 'strontium ranelate', 'periodontics', 'dental implantology', 'oral surgery', 'orthodontics' and 'endodontics', PubMed/Medline, Lilacs and BBO electronic databases were searched for research articles, reviews of literature, animal laboratory studies and laboratory studies, which had been published in English until July 2020 . Twenty-five articles fulfilled the inclusion and exclusion criteria. The available literature demonstrates that SRAN provides a really better propaedeutic on the bone tissue and that the topical applications show a lower risk of side effects. That open up new perspectives and for the use of SRAN as a potential storage media for avulsed teeth.

Descriptors: Strontium; Pharmaceutical Preparations; Periodontics; Endodontics; Surgery, Oral; Dental Implantation.

\section{Resumo}

A avulsão dentária ainda é um problema de saúde pública e o reimplante dentário apresenta índices importantes de insucesso devido à reabsorção radicular. O ranelato de estrôncio (SRAN) apresenta propriedade antirreabsortiva no tecido ósseo e estimula a formação óssea. Assim, objetivamos realizar uma revisão abrangente da literatura para 1- compreender o mecanismo de ação do SRAN quanto à sua propedêutica em periodontia, implantologia dentária, cirurgia oral, ortodontia e endodontia; 2- apresentar o conhecimento científico atual sobre a eficiência do SRAN na avulsão dentária; 3- observar lacunas na literatura e abrir para ideias inexploradas para usos e aplicações de SRAN. Foi realizada uma busca eletrônica cruzando as palavras-chave 'strontium ranelate', 'periodontics', 'dental implantology', 'oral surgery', 'orthodontics' and 'endodontics', PubMed / Medline, Lilacs e bancos de dados eletrônicos BBO foram pesquisados. Artigos, revisões de literatura, estudos laboratoriais em animais e estudos laboratoriais, publicados em inglês até julho de 2020. Vinte e cinco artigos preencheram os critérios de inclusão e exclusão. A literatura disponível demonstra que o SRAN proporciona uma propedêutica realmente melhor no tecido ósseo e que as aplicações tópicas apresentam menor risco de efeitos colaterais. Isso abre novas perspectivas e para o uso de SRAN como um meio de armazenamento potencial para dentes avulsionados.

Descritores: Estrôncio; Preparações Farmacêuticas; Periodontia; Endodontia; Cirurgia Bucal; Implantação Dentária.

\section{Resumen}

La avulsión dental sigue siendo un problema de salud pública y la reimplantación de dientes tiene importantes tasas de fracaso debido a la reabsorción radicular. El ranelato de estroncio (SRAN) presenta propiedades antirresortivas en el tejido óseo y estimula la formación de hueso. Por lo que nos propusimos hacer una revisión exhaustiva de la literatura para 1- comprender el mecanismo de acción de SRAN en cuanto a su propedéutica en periodoncia, implantología dental, cirugía oral, ortodoncia y endodoncia, 2 - presentar el conocimiento científico actual sobre la eficiencia de SRAN en avulsión dental; 3- observar fallas y lagunas en la literatura y abrirse a ideas inexploradas para usos y aplicaciones de SRAN. Se realizó una búsqueda electrónica cruzando las palabras clave 'strontium ranelate', 'periodontics', 'dental implantology', 'oral surgery', 'orthodontics' and 'endodontics', se realizaron búsquedas en bases de datos electrónicas PubMed / Medline, Lilacs y BBO para la investigación artículos, revisiones de literatura, estudios de laboratorio en animales y estudios de laboratorio, que habían sido publicados en inglés hasta julio de 2020 . Veinticinco artículos cumplieron los criterios de inclusión y exclusión. La literatura disponible demuestra que SRAN proporciona una propedéutica realmente mejor en el tejido óseo y que las aplicaciones tópicas muestran un menor riesgo de efectos secundarios. Eso abre nuevas perspectivas y para el uso de SRAN como medio de almacenamiento potencial para dientes avulsionados.

Descriptores: Estroncio; Preparaciones Farmacéuticas; Periodoncia; Endodoncia; Cirugía Bucal; Implantación Dental.

\section{INTRODUCTION}

Traumatic injuries are regarded serious social problems and pose a health risk worldwide. Among them, traumatic dental injuries are an important category ${ }^{1}$. The highest frequency of traumatic dental injures is in preschoolers, school-age children and young adults $^{2}$. Glendor et al. reported that $25 \%$ and $33 \%$ of population have experienced dental trauma, for schoolchildren and adults, respectively ${ }^{3}$.
Traumatic dental injuries have a multifactorial and complex etiology. Glendor et al. 2009 suggested that three main etiologic factors: 1- "environmental determinants", which includes more contextual parameters, such as individual protection equipment deprivation or an unsafe environment; 2- "human behavior" including risk-taking behaviors, conditions such as hyperactivity/attention-deficit, and others; and 3- "oral factors", wherein are included increased 
overjet with protrusion, lip incompetence and others intraoral and extraoral factors. Obviously, this triad is not all-inclusive list, but offers a helpful categorization of all postulated risk factor of traumatic dental injuries ${ }^{4}$. Zaleckiene et al. ${ }^{5}$ proposed additional risk factors like body mass index, sex, inappropriate use of teeth, physical limitations, presence of illness, oral piercings and learning difficulties. Those do not necessarily fall into one of Glendor's categories, but might also increase the risk of dental trauma ${ }^{5}$.

Anterior teeth, especially maxillary central and lateral incisors, are the most affected by traumatic dental injuries. Usually a single tooth is affected, however due to sports and/or traffic accidents and violence, multiple teeth can be affected $^{3}$. In primary dentition, Luxation injuries and crown factors are the representatives of traumatic dental injuries for primary and permanent dentition, respectively ${ }^{2}$.

Among all traumatic dental injuries, tooth avulsion has a prevalence from 0.5 to $15 \%$ in permanent dentition ${ }^{6,7}$, and it is defined as the complete displacement of the tooth out of its socket with disruption of the fibers of periodontal ligament and blood supply, beyond the aggression in cementum and alveolar bone., Clinical prognosis of avulsion is very contingent on first-aid measures and quickness to seek dental care ${ }^{10,11}$.

The best clinical protocol for avulsed teeth is the immediate replantation ${ }^{12}$ and its success is dependent of high management knowledge, training and quickness, what makes the immediate replantation impracticable ${ }^{13}$. So, an alternative is to perform late replantation, in which storage media for avulsed teeth plays an important role to lead to high level of success, otherwise tooth loss can happen mostly because a replacement resorption and inflammatory resorption of $\operatorname{root}^{12,14,15}$.

Strontium Ranelate (SRAN) is an antiresorptive and bone pro-forming agent that can minimize, by demonstrations of numerous clinical studies, the risk of nonvertebral, vertebral and hip fractures in a wide range of post-menopausal woman with osteoporosis. Therefore, SRAN has been used for this group of patients for more than 10 years $^{16}$. When compared to other drugs, SRAN has a dual action on bone tissues simultaneously that result in anabolic and antiresorptive drug while reduce the lifespan of osteoclasts, stimulates osteoblast recruitment and activity ${ }^{17}$.

Despite strontium ranelate demonstrating good properties to bone tissue, the systemic administration shows some side effects mostly cardiovascular events ${ }^{16}$. However, some studies provide bases to suppose that these risks can be lower when at topical application ${ }^{18,19,20}$.

Therewith, combining the action of SRAN on the bone tissue and the possibility of topical application is reasonable to consider that drug as a storage media for avulsed teeth, wherein the antiresorptive mechanism could prevent the root resorption after replantation.

Thus, we aimed to perform a literature review to 1- understand the mechanism of action of SRAN regarding to its propaedeutic in periodontics, dental implantology, oral surgery, orthodontics and endodontics, 2- present the current scientific knowledge about the SRAN efficiency on tooth avulsion; 3- observe fails and gaps in the literature and open up for unexplored ideas for SRAN uses and applications.

MATERIAL AND METHOD

Using the key words 'strontium ranelate', 'periodontics', 'dental implantology', 'oral surgery', 'orthodontics' and 'endodontics', PubMed/Medline, Lilacs and BBO electronic databases were searched for research articles, reviews of literature, animal laboratory studies and laboratory studies, which had been published in English until July 2020. Papers without an abstract and those that did not evaluated dentistry parameters using strontium ranelate were not included. Twenty-five articles were select after application of the inclusion and exclusion criteria and were critically review for comparison of the outcomes.

LITERATURE REVIEW

Strontium Ranelate (SRAN) is a drug that contains two atoms of stable strontium $\left(\mathrm{Sr}^{2+}\right)$, which is a bivalent calcium-like cation, and an organic acid (Ranelic acid). ${ }^{21}$ This salt possesses a high affinity to the mineral phase of bone - hydroxyapatite (HAp), demonstrating ability to bind with it and, under certain conditions, present a similar metabolism to $\mathrm{Ca}^{2+}$. However, even the SRAN presents attraction to bone tissue, the atomic integration is still low, and some studies reported that only one in ten $\mathrm{Ca}^{2+}$ atoms could be replace by strontium. Thereby, the mixed results regarding the benefit of using this drug stem from the fact that they are dependents of the variety of doses used and the multiple induction models employed ${ }^{22}$.

The exact mechanism of action of SRAN has not entirely understood. However, the studies over the years had considered as possible mediators of the pharmacological properties: stimulation of osteoblast proliferation, inhibition of osteoclast formation with probable apoptosis of mature cells, regulation of bone cell and activation of calcium-sensitive receptors ${ }^{22}$. 
Thereby, could be concluded that SRAN has a very peculiar dual action: stimulate bone formation and decrease bone resorption ${ }^{16,21}$.

The protective properties of SRAN in bone was first described in 1959 when strontium lactate was reported as capable of increasing bone density and decreasing pain in a small study of patients with osteoporosis ${ }^{22}$. Through clinical trials, SRAN has been shown significantly improve bone mass and quality, besides doing changes in bone matrix properties and bone mineral density, increasing bone strength. Moreover, it can reduces the risk of spine or hip fractures ${ }^{16}$. This drug has been used, for more than 10 years, for postmenopausal osteoporosis in woman and man and is a registered medication in over than 70 countries $^{16}$.

In view of the benefits of SRAN on the bone tissue, some studies have been associating this medication in the dentistry field. Buehler et al. 2001 evaluated the histomorphometry aspects of a right halfmandible removed of 30 cynomolgus monkeys (Macaca fascicularis), separated at random, after 26 weeks treated daily with SRAN or saline. Thus, strontium ranelate presented a significantly reduction of bone resorption indices while was able to maintain bone formation in alveolar. This study was one of the precursors to studies with SRAN on differents areas and pathologies of dentistry ${ }^{23}$.

\section{- Periodontics}

Periodontal disease is a common chronic inflammatory disease characterized by destruction of the tooth-supporting tissues, including periodontal-ligament, cementum and alveolar bone. Non-surgical therapies (with or without adjuncts) including scaling and root planning (SRP) are simple and effective procedures for treating periodontitis ${ }^{24}$. Some researches have been done to try stopping the bone loss throughout of a more efficient way and some of them used SRAN.

In a study with ligature-induced periodontitis in rats, Karakan et al. $^{25}$ demonstrated the influence that systemic administration of SRAN have on the alveolar bone loss. SRAN effectively increased bone mass and resistance and reduced bone loss. Furthermore, the drug could reduce osteoclast numbers in rats with periodontitis. Corroborating with this result, Souza et al. ${ }^{17}$ and Marins et al. ${ }^{26}$ have observed the same pattern using SRAN in rats with periodontitis. Marins el al. $^{17}$ also concluded that the drug affected the expression of bone markers, showing to act predominantly as an anti-resorptive agent.
Er et al. $^{27}$ evaluated the cytotoxicity of SRAN on cultured human periodontal ligament fibroblasts obtained from healthy human third molars. They could conclude that SRAN was non-toxic at appropriate concentrations, but cultures treated with highest concentrations had significantly lower cell numbers and cells viability. In the same line, Bizelli-Silveira et al. 2018 have observed that PDL cells responded to SRAN with increased cellular proliferation and osteogenic behavior ${ }^{28}$.

In order to increase the SRAN response, Wei et al. 2014 combined SRAN with the mesoporous bioactive glass (MBG) scaffolds. The results showed periodontal regeneration in rats with periodontal fenestration defects, even in severely osteoporotic animals ${ }^{29}$. Further, Jia et al. 2019 discovered a splicing factor, heterogeneous nuclear ribonucleoprotein $\mathrm{L}$ (hnRNPL), was drastically down-regulated in periodontal ligament stem cells stimulated by $\mathrm{Sr}$ through the activation of AKT pathway. Furthermore, hnRNPL restrained the osteogenic differentiation of periodontal ligament stem cells through down-regulating H3K36me3-specific methyltransferase Setd $2^{30}$.

○ Implantology

Dental implants represent a secure treatment option in oral rehabilitation and Brånemark et al. 1969 first described the process of osseointegration ${ }^{31}$. In general, the long-term survival rates of dental implants are excellent, but failures still occur in a small quantity of cases. These prompt the need for researches with bioactive surface modifications whose objective is to facilitate early osseointegration $^{32}$. Thus, it was suggests that the use of SRAN might be benefic in that point.

Park et al. ${ }^{33}$ evaluated Ti-6Al-4V alloy implants incorporated with strontium ions inserted in tibial and femoral condyles of rabbits. Four weeks later, implants containing strontium showed significantly more bone-implant contact in both cortical and cancellous bone.Zhao $L$ et al. ${ }^{34}$ corroborated with the results when showed that incorporation of strontium within the Titanium/Sr nanotubes enhanced the proliferation of mesenchymal stem cell and osteoblastic differentiation in rats.

Through systemic administration of SRAN for 8 weeks after the surgery for insertion of titanium implants, Maïmoun et al. ${ }^{35}$ obtained a remarkably similar result. This study concluded that SRAN had a significant beneficial effect on parameters of bone biomaterial properties at both cortical and trabecular areas. Tian et al. ${ }^{36}$ corroborated with these results with a study that used a strontium ranelate-loaded chitosan film 
on a titanium surface, which promoted osteoblasts proliferation and differentiation in a dose-dependent manner.

De Bonis et al. ${ }^{37}$ made a study whose method was based on the combination of a mechanochemical synthesis of $\mathrm{Sr}-\mathrm{Ha}$ targets and their deposition in form of thin films on top of titanium with the use of laser ablation at low pressure. They could conclude that the bioactivity and biocompatibility of Sr-HA were confirm in an interaction with dental pulp stem cells, suggesting that these coatings may be viable candidates for the surface components of metallic bone implants.

On the other hand, Alenezi et al. $^{38}$ evaluated whether the local release of strontium ranelate (Sr-ranelate) from implants coated with mesoporous titania could improve bone formation around implants in an animal model. SEM images and histomorphometric analysis showed the successful formation of bone, but with no significant differences to the control group, so they have concluded that, regarding to the results, it is not possible to confirm the positive effects of SRAN on implant osseointegration.

- Surgery

Rapid bone defect filling with normal bone is a challenge in dentistry. Infection, dental extraction, bone metastasis, comminuted fractures and orthopedic surgery are among the main causes leading to a local bone loss ${ }^{39,40}$.

Zacchetti et al. ${ }^{41}$ demonstrated that the systemic administration of SRAN accelerates the healing of a bone defect created in rat proximal tibiae. SRAN was integrated both in cortical and in trabecular bone after 8 and 12 weeks of bone defect surgery.

Lavet et al. ${ }^{42}$ treat with SRAN proximal tibia bone defects created in rats. This study reported that, in the healing zone, the medication stimulated bone formation early and latterly decreased bone resorption, improving the healing of the trabecular and cortical compartment without deleterious effects on bone quality.

\section{- Orthodontics}

The anchorage mechanisms currently used in orthodontic treatment have various disadvantages ${ }^{43}$. Orthodontically induced external root resorption (OIERR) is a deleterious common side effect of orthodontic movements, which are inflammation-driven tooth movement. OIERR thus occurs when is exceeded the reparative capacity of the cementum, what exposes the dentine to activated odontoclasts, causing irreversible loss of root structure ${ }^{44}$.

Kirschneck et al. ${ }^{45}$ reported that SRAN significantly reduced tooth movement and root resorption in anchorage orthodontic of rats after two and four weeks. ${ }^{45}$ Makrygiannakis et al. ${ }^{46}$ corroborated with that when, investigating the effect of commonly prescribed systemic medications, shows that strontium ranelate decreased the rate of orthodontic tooth movement.

The effects of SRAN is also been study in the mid-palatal suture after rapid maxillary expansion (RME). Zhao et al. ${ }^{47}$ investigated the morphological changes in the mid-palatal suture of rats 4, 7 and 10 days after and orthodontic appliance was set between the right and left upper molars with an expansive force. It was report that strontium ranelate can increase bone formation, have some influence on remodeling of the alveolar bone in the molars and may be effective in preventing relapse after RME.

\section{- Endodontics}

The pulp treatment has a purpose to maintain the tooth structure intact in order to preserve vitality and function of teeth damaged due to trauma or dental caries. In case of immature permanent teeth, maintain the pulp vitality is essential for continuous root development and apical closure ${ }^{48}$.

Huang et al. ${ }^{49}$ characterize the Sr effects on human dental pulp stem cells human dental pulp cells (HDPCs) in vitro using exogenously $\mathrm{Sr}$ added to culture medium, and bioavailable $\mathrm{Sr}$ derived from a novel bioactive glass. This study reported that, at specific doses, Sr significantly influences proliferation, odontogenic mineralization and differentitation of HDPCs in vitro via the calcium-sensing receptor (CaSR) using a similar pathway to osteoblast differentiation.

Mizumachi et al. ${ }^{50}$ corroborated with these results when examined the expression of CaSR in both rat dental pulp tissue and human dental pulp cells and investigated the effects of activated CaSR on odontoblastic differentiation of HDPCs. This study reported that in rats, CaSR was expressed throughout the pulp tissue, with higher expression levels in the odontoblastic layer and lower levels in central pulp tissue. That suggest that use of a CaSRactivating agent under a neutral $\mathrm{pH}$ conditions may be an ideal therapeutic medication due to less tress for pulp tissue, leading to the induction of normal dentin formation without necrotic layers.

Bakhit et al. ${ }^{19}$ investigated the effects of strontium ranelate on the proliferation and mineralization/differentiation of cloned dental pulp-like cells (mouse dental papillae cells; MDPs). This in vivo study reported that topical 
application of SRAN induced a continuous barrier of osteodentin-like mineralized tissue on the rat exposed pulp tissue, what shows that this drug has a potential utility as a new pulpcapping material.

DISCUSSION

Besides being used mostly for osteoporosis, studies are being done to investigate the complete mechanism of action and the influence that SRAN exercise on the oral tissues repair. The included studies investigated the use of SRAN on procedures that involves periodontics, implantology, surgery, orthodontics and endodontics. Based on the results of these studies, is reasonable considerate new studies using this drug on a field not yet researched, such as in cases of tooth avulsion, because of its potential beneficial effect on the avulsed teeth through root surface treatment or as a storage media.

On periodontics, SRAN showed capable to act predominantly as an anti-resorptive agent ${ }^{17}$ increase bone resistance and mass and reduce bone loss through reduction of osteoclast numbers in rats ${ }^{17,25}$. SRAN is also capable to increase cellular proliferation on the PDL cells ${ }^{28}$. SRAN showed more bone-implant contact in both cortical and cancellous bone and increased the proliferation of mesenchymal stem cells and osteoblastic differentiation in rats $^{33,34}$. SRAN showed benefits effects on parameters of bone biomaterial properties at both cortical and trabecular areas ${ }^{35}$. Also, the biocompatibility and bioactivity of SRAN were confirm in an interaction with dental pulp stem cells ${ }^{37}$. Furthermore, SRAN seems to accelerate the healing of a bone defect, stimulating bone formation and decreasing bone resorption without deleterious effects on bone quality ${ }^{41,42}$.

SRAN was also studied related with orthodontic treatment. It was observed that it had the ability to reduce the rate of tooth movement and root resorption in anchorage ${ }^{45,46}$; and also presents benefits on the tissue repair after rapid maxillary expansion (RME) by accelerating bone deposition calcification and new bone formation ${ }^{47}$. Some studies reported that SRAN influences, on endodontics treatment, proliferation, odontogenic mineralization and differentiation of HDPCs at specific doses ${ }^{49,50}$, leading to the induction of normal dentin formation without necrotic layers $^{19,50}$.

The systemic side effects of SRAN should be also discuss and taken into account. They include venous thromboembolism, cardiovascular events, gastrointestinal discomfort, nausea, myocardial infarction and others systemic symptoms ${ }^{16}$. However, based in some studies, it is reasonable to suppose that topical application may pose a much lower risk of side effects compared to systemic application ${ }^{18-20}$. Er et al. ${ }^{27}$ analyzed the cytotoxicity of this drug on human periodontal ligament fibroblasts (PDL cells) in vitro. This study concluded that, at appropriate concentrations, SRAN was non-toxic to the PDL cells.

These results open up new perspectives for the use of SRAN in studies as a pharmacologic agent, with a potential beneficial effect on the avulsed teeth through root surface treatment or as a storage media. So far, there are not available studies that related this drug for this purpose.

In cases of tooth avulsion, dry storage is detrimental to the preservation of the PDL cells, so the avulsed tooth must be prevented from drying by the use of storage media. Among the ideal requirements of a storage media, it should be capable of preserving the feasibility of PDL cells, not react with body fluids, have antimicrobial characteristics and physiological $\mathrm{pH}$ and preferably capacity of proliferate cells. Available at literature search, there are many solutions tested as a storage media: saline solution, saliva, tap water, pasteurized milk, Hank's Balanced Salt Solution (HBSS), eagle's medium, propolis, egg white, coconut water, green tea extract, oral rehydration salt-liquid, tooth rescue box, contact lens solutions, Gatorade, among others ${ }^{12,51}$.

Khinda et al. ${ }^{51}$ concluded that HBSS and pasteurized milk are the most appropriate clinically recommended storage media. Gatorade, saliva, saline, tap water and contact lens solution have been not recommended due to be considered non-physiological. Pasteurized milk, propolis, coconut water and egg white have shown promising results.

The prognosis of a replanted tooth depends on conditions related to the extraalveolar time and type of storage media: viability of PDL cells remaining on root surface, minimal bacterial contamination and integrity of root cementum $^{12}$. Is crucial maintaining PDL vitality for a good prognosis since the presence of necrotic PDL remnants can cause the development of root resorption ${ }^{52}$.

Even with all these knowledge about the correlation between the conditions like storage media, studies are still been done trying to find a storage media that could provide more confidence on a favorable prognosis. Considering the benefits of SRAN on the periodontal tissue repair, researches should be 
done using it as a storage media for avulsed tooths and replantation varying concentrations and time of storage. If with positive results, studies in human should be encouraged.

\section{REFERENCES}

1. Azami-Aghdash S, Ebadifard Azar F, Pournaghi Azar F, et al. Prevalence, etiology, and types of dental trauma in children and adolescents: systematic review and meta-analysis. Med $\mathrm{J}$ Islam Repub Iran. 2015;29(4):234.

2. Diangelis AJ, Andreasen JO, Ebeleseder KA, et al. International Association of Dental Traumatology guidelines for the management of traumatic dental injuries: 1. Fractures and luxations of permanent teeth. Dent Traumatol. 2012;28(1):2-12.

3. Glendor U. Epidemiology of traumatic dental injuries--a 12 years review of the literature. Dent Traumatol. 2008;24(6):603-11.

4. Glendor U. Aetiology and risk factors related to traumatic dental injuries--a review of the literature. Dent Traumatol. 2009;25(1):19-31.

5. Zaleckiene V, Peciuliene V, Brukiene V, Drukteinis S. Traumatic dental injuries: etiology, prevalence and possible outcomes. Stomatologija. 2014;16(1):7-14.

6. Viegas CM, Scarpelli AC, Carvalho AC, Ferreira FM, Pordeus IA, Paiva SM. Predisposing factors for traumatic dental injuries in Brazilian preschool children. Eur J Paediatr Dent. 2010; 11(2):59-65.

7. Wendt FP, Torriani DD, Assunção MC, Romano AR, Bonow ML, da Costa CT et al. Traumatic dental injuries in primary dentition: epidemiological study among preschool children in South Brazil. Dent Traumatol. 2010; 26(2):168-73.

8. Moura CC, Soares PB, de Paula Reis MV, Fernandes AJ Neto, Zanetta Barbosa D, Soares CJ. Potential of coconut water and soy milk for use as storage media to preserve the viability of periodontal ligament cells: an in vitro study. Dent Traumatol. 2014;30:22-6.

9. Veras SRA, Bem JSP, de Almeida ECB, Lins CCDSA. Dental splints: types and time of immobilization post tooth avulsion. J Istanb Univ Fac Dent. 2017;51 (3 Suppl 1):S69-S75.

10. Andersson L, Andreasen JO, Day P, Heithersay G, Trope M, Diangelis AJ et al. International Association of Dental Traumatology guidelines for the management of traumatic dental injuries: 2. Avulsion of permanent teeth. Dent Traumatol. 2012;28:88-96.

11. Santos ME, Habecost AP, Gomes FV, Weber $\mathrm{JB}$, de Oliveira MG. Parent and caretaker knowledge about avulsion of permanent teeth. Dent Traumatol 2009;25:203-8.

12. Poi WR, Sonoda CK, Martins CM, Melo ME, Pellizzer EP, de Mendonca MR et al. Storage media for avulsed teeth: a literature review. Braz Dent J. 2013;24:437-45.
13.Zafar K, Ghafoor R, Khan FR, Hameed MH. Awareness of dentists regarding immediate management of dental avulsion: Knowledge, Attitude, and Practice study. J Pak Med Assoc. 2018;68(4):595-99.

14. Heydari A, Tahmasbi S, Badiee M, Izadi S, Mashhadi Abbas F, Mokhtari S. The Effect of Root Coating with Titanium on Prevention of Root Resorption in Avulsed Teeth: An Animal Study. Iran Endod J. 2016;11(4):309-14.

15. Kristerson L, Soder PO, Otteskog P. Transport and storage of human teeth in vitro for autotransplantation and replantation. J Oral Surg. 1976;34:13-8.

16. Pilmane M, Salma-Ancane K, Loca D, Locs J, Berzina-Cimdina L. Strontium and strontium ranelate: Historical review of some of their functions. Mater Sci Eng C Mater Biol Appl. 2017;78:1222-30.

17. Marins LM, Napimoga MH, Malta FS, et al. Effects of strontium ranelate on ligature-induced periodontitis in estrogen-deficient and estrogensufficient rats. J Periodontal Res. 2020; 55(1):141-51.

18. Yang F, Yang D, Tu J, Zheng Q, Cai L, Wang L. Strontium enhances osteogenic differentiation of mesenchymal stem cells and in vivo bone formation by activating Wnt/catenin signaling. Stem Cells. 2011;29(6):981-91.

19. Bakhit A, Kawashima N, Hashimoto K, Noda S. Strontium ranelate promotes odonto/osteogenic differentiation/mineralization of dental papillae cells in vitro and mineralized tissue formation of the dental pulp in vivo. Sci Rep. 2020;10(1):8375.

20. Silva GAB, Bertassoli BM, Sousa CA, Albergaria JD, de Paula RS, Jorge EC. Effects of strontium ranelate treatment on osteoblasts cultivated onto scaffolds of trabeculae bovine bone. J Bone Miner Metab. 2018;36(1):73-86.

21. Scardueli CR, Bizelli-Silveira C, Marcantonio RAC, Marcantonio E Jr, Stavropoulos A, SpinNeto R. Systemic administration of strontium ranelate to enhance the osseointegration of implants: systematic review of animal studies. Int J Implant Dent. 2018;4(1):21.

22. Rodrigues TA, Freire AO, Bonfim BF, Cartágenes MSS, Garcia JBS. Strontium ranelate as a possible disease-modifying osteoarthritis drug: a systematic review. Braz J Med Biol Res. 2018;51(8):e7440.

23. Buehler J, Chappuis P, Saffar JL, Tsouderos Y, Vignery A. Strontium ranelate inhibits bone resorption while maintaining bone formation in alveolar bone in monkeys (Macaca fascicularis). Bone. 2001;29(2):176-79.

24.Zhao X, Liu Z, Shu D, Xiong Y, He M, Xu S et al. Association of periodontitis with rheumatoid arthritis and the effect of non-surgical periodontal treatment on disease activity in patients with rheumatoid arthritis. Med Sci Monit. 2018;24:5802-10. 
25. Karakan NC, Akpınar A, Göze F, Poyraz Ö. Investigating the Effects of Systemically Administered Strontium Ranelate on Alveolar Bone Loss Histomorphometrically and Histopathologically on Experimental Periodontitis in Rats. J Periodontol. 2017; 88(2):e24-e31.

26. Souza RB, Gomes FIF, Pereira KMA, Dutra PGP, Cunha RMS, Chaves HV et al. Strontium Ranelate elevates expression of heme oxygenase- 1 and decreases alveolar bone loss in rats. J Oral Maxillofac Res. 2018;9(4):e4.

27. Er K, Polat ZA, Ozan F, Taşdemir T, Sezer U, Siso SH. Cytotoxicity analysis of strontium ranelate on cultured human periodontal ligament fibroblasts: a preliminary report. J Formos Med Assoc. 2008;107(8):609-15.

28. Bizelli-Silveira C, Pullisaar $H$, Abildtrup LA, Andersen OZ, Spin-Neto $R$, Foss $M$ et al. Strontium enhances proliferation and osteogenic behavior of periodontal ligament cells in vitro. J Periodontal Res. 2018; 53(6):1020-28.

29. Wei L, Ke J, Prasadam I, Miron RJ, Lin S, Xiao $\mathrm{Y}$, Chang $\mathrm{J}$ et al. A comparative study of Srincorporated mesoporous bioactive glass scaffolds for regeneration of osteopenic bone defects. Osteoporos Int. 2014;25(8):2089-96.

30. Jia X, Miron RJ, Yin C, Xu H, Luo T, Wang J et al. HnRNPL inhibits the osteogenic differentiation of PDLCs stimulated by $\mathrm{SrCl} 2$ through repressing Setd2. J Cell Mol Med. 2019;23(4):2667-77.

31. Brånemark PI, Adell R, Breine U, Hansson BO, Lindström J, Ohlsson A. Intra-osseous anchorage of dental prostheses. I. Experimental studies. Scand J Plast Reconstr Surg. 1969; 3(2):81-100.

32. Smeets R, Stadlinger B, Schwarz F, et al. Impact of Dental Implant Surface Modifications on Osseointegration. Biomed Res Int. 2016; 2016:6285620.

33. Park JW, Kim HK, Kim YJ, Jang JH, Song $H$, Hanawa T. Osteoblast response and osseointegration of a Ti-6Al-4V alloy implant incorporating strontium. Acta Biomater. 2010; 6(7):2843-2851.

34.Zhao L, Wang $\mathrm{H}$, Huo $\mathrm{K}$, Zhang $\mathrm{X}$, Wang $\mathrm{W}$, Zhang $Y$ et al. The osteogenic activity of strontium loaded titania nanotube arrays on titanium substrates. Biomaterials. 2013;34(1): 19-29.

35. Maïmoun L, Brennan TC, Badoud I, DuboisFerriere V, Rizzoli R, Ammann P. Strontium ranelate improves implant osseointegration. Bone. 2010;46(5):1436-41.

36. Tian A, Zhai JJ, Peng $Y$, Zhang L, Teng $\mathrm{MH}$, Liao $\mathrm{J}$ et al. Osteoblast response to titanium surfaces coated with strontium ranelate-loaded chitosan film. Int J Oral Maxillofac Implants. 2014;29(6):1446-53.
37. De Bonis A, Uskoković V, Barbaro K, Fadeeva I, Curcio M, Imperatori $L$ et al. Pulsed laser deposition temperature effects on strontiumsubstituted hydroxyapatite thin films for biomedical implants. Cell Biol Toxicol. 2020;10.1007/s10565-020-09527-3.

38. Alenezi A, Galli S, Atefyekta S, Andersson M, Wennerberg A. Osseointegration effects of local release of strontium ranelate from implant surfaces in rats. J Mater Sci Mater Med. 2019; 30(10):116.

39. Ozer M, Akdeniz BS, Sumer M. Alveolar ridge expansion-assisted orthodontic space closure in the mandibular posterior region. Korean $\mathrm{J}$ Orthod. 2013;43(6):302-310.

40. Park TK, Vargervik K, Oberoi S. Orthodontic and surgical management of cleidocranial dysplasia. Korean J Orthod. 2013;43(5):248-60.

41.Zacchetti G, Dayer R, Rizzoli R, Ammann P. Systemic treatment with strontium ranelate accelerates the filling of a bone defect and improves the material level properties of the healing bone. Biomed Res Int. 2014; 2014:549785.

42. Lavet C, Mabilleau G, Chappard D, Rizzoli R, Ammann P. Strontium ranelate stimulates trabecular bone formation in a rat tibial bone defect healing process. Osteoporos Int. 2017; 28(12):3475-87.

43. Feldmann I, Bondemark L. Orthodontic anchorage: a systematic review. Angle Orthod. 2006;76(3):493-501.

44. Currell SD, Liaw A, Blackmore Grant PD, Esterman A, Nimmo A. Orthodontic mechanotherapies and their influence on external root resorption: A systematic review. Am J Orthod Dentofacial Orthop. 2019;155(3): 313-29.

45. Kirschneck C, Wolf M, Reicheneder C, Wahlmann U, Proff P, Roemer P. Strontium ranelate improved tooth anchorage and reduced root resorption in orthodontic treatment of rats. Eur J Pharmacol. 2014;744:67-75.

46. Makrygiannakis MA, Kaklamanos EG, Athanasiou AE. Does common prescription medication affect the rate of orthodontic tooth movement? A systematic review. Eur J Orthod. 2018;40(6):649-59.

47.Zhao S, Wang X, Li N, Chen Y, Su Y, Zhang J. Effects of strontium ranelate on bone formation in the mid-palatal suture after rapid maxillary expansion. Drug Des Devel Ther. 2015;9: 2725-34.

48. Lee BN, Moon JW, Chang HS, Hwang IN, Oh WM, Hwang YC. A review of the regenerative endodontic treatment procedure. Restor Dent Endod. 2015;40(3):179-87.

49. Huang M, Hill RG, Rawlinson SC. Strontium (Sr) elicits odontogenic differentiation of human dental pulp stem cells (hDPSCs): A therapeutic role for $\mathrm{Sr}$ in dentine repair?. Acta Biomater. 2016;38:201-11. 
50. Mizumachi H, Yoshida S, Tomokiyo A, Hasegawa D, Hamano S, Yuda A et al. Calcium-sensing receptor-ERK signaling promotes odontoblastic differentiation of human dental pulp cells. Bone. 2017;101:191-201.

51. Is Khinda V, Kaur G, S Brar G, Kallar S, Khurana $\mathrm{H}$. Clinical and Practical Implications of Storage Media used for Tooth Avulsion. Int J Clin Pediatr Dent. 2017;10(2):158-65.

52. Tuna EB, Yaman D, Yamamato $S$. What is the Best Root Surface Treatment for Avulsed Teeth?. Open Dent J. 2014;8:175-79.

\section{CONFLICTS OF INTERESTS}

The authors declare no conflicts of interests.

\section{CORRESPONDING AUTHOR}

\section{Christine Men Martins}

Endodontic area,

Dental School of Presidente Prudente,

University of Western São Paulo - UNOESTE

José Bongiovani Street, number 700,

19050-920, Presidente Prudente - SP, Brasil

Tel.: +55 (44) 99927-831

E-mail: christinemen@hotmail.com 